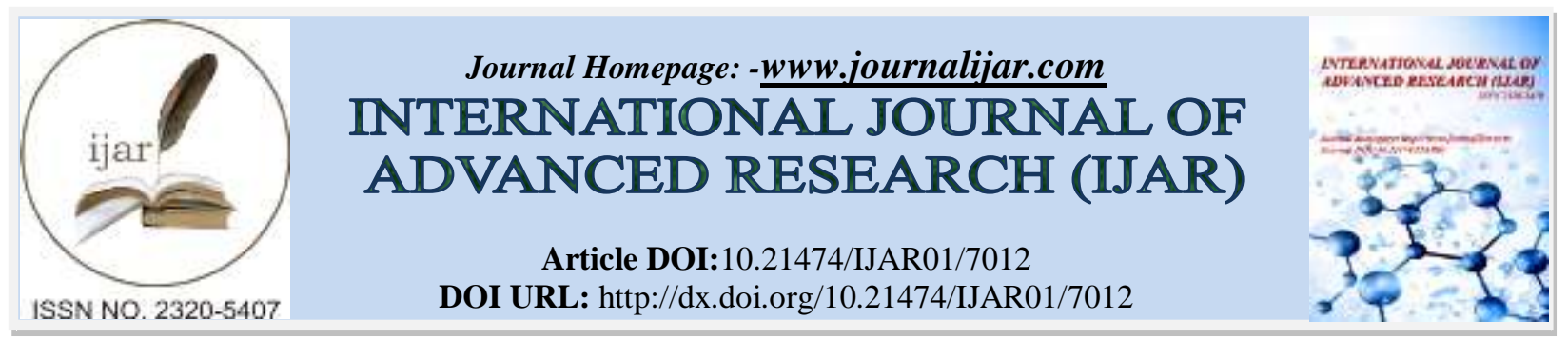

RESEARCH ARTICLE

\title{
BIOREMEDIATION OF MUNICIPAL SEWAGE WATER WITH AZOLLA MICROPHYLLA
}

\author{
Divya Soman ${ }^{1}$, Anitha $V^{2}$ and Anju Arora ${ }^{3}$. \\ 1. Research Scholar, Kerala Forest Research Institute, Peechi. \\ 2. Senior Scientist, Kerala Forest Research Institute, Peechi. \\ 3. Senior Scientist, Indian Agricultural Research Institute, New Delhi.
}

\section{Manuscript Info}

\section{Manuscript History}

Received: 01 March 2018

Final Accepted: 03 April 2018

Published: May 2018

Keywords:-

Azolla, bioremediation, wastewater treatment.

\begin{abstract}
Population rise coupled with urbanization and industrialization has resulted in over exploitation of ground water resources and lowering of the water table in many areas. The availability of clean water is at stake when the modern agricultural activities demands more water for irrigational activities. Various treatment systems which are a combination of physical, chemical or biological processes are used for purification and recycling of water. But these are expensive and unaffordable to common man. Bioremediation is an excellent, low cost option to ward off the pollutants. It has been successfully used in constructed wetlands, an ecosystem with the assemblage of plants, microbes and the abiotic factors. The paper analyses the ability of Azolla to remove nutrients from secondary treated sewage water which if released directly to water bodies result in eutrophication. The present study analyses the nutrient removal capacity of Azolla from waste water and shows that the growth of Azolla remove 54.8 per cent ammonia, 50 percent total organic carbon, 33.3 percent organic matter, 71.4 per cent nitrite, 68.65 per cent available phosphorous and 80.52 per cent total phosphorous from wastewater and prevents the eutrophication in water bodies.
\end{abstract}

Copy Right, IJAR, 2018,. All rights reserved.

\section{Introduction:-}

Increased industrialization, urbanization and rapid population explosion has given way to increased environmental pollution (CPCB, 2008; Arora et.al. 2009; Sood et al., 2011; Sachdeva and Sharma, 2012). The pollutants in the form of organics from herbicides, insecticides and inorganics like trace elements, heavy metals and metalloids are being discharged into different compartments of earth- soil, water and air. Pollutants are getting added with irrigation water rendering the agricultural soil unproductive by turning them saline. In modern agriculture there is a need for intensive irrigation. This has resulted in over exploitation of ground water resources and lowering of the water table turning many areas drought affected. The world will eventually face a war like situation for water and the disputes between different states for water sharing is already in the anvil. The 3R principle of Reduce, Recycle and Reuse is the solution to the problem of water scarcity and maintaining sustainability in water usage and it becomes mandatory to recycle wastewater. Conventional wastewater treatment processes includes physical, chemical and biological methods which are commonly expensive. Hence, cost effective and efficient method of wastewater treatment through the use of constructed wetland has gained its importance. 
India which was once a treasure house of wetland, the natural water purifiers and one among the richest holders of biodiversity is tremendously being affected by the agricultural development and land use changes (Bassi et al., 2014). Decline in the natural wetland which are capable of assimilating the pollutants with their self-regulating nature, has led to design and construction of artificial wetlands. The use of constructed wetlands for treating wastewater has gained its importance since 1950 (Vymazal, 2010) and is increasingly used due to its low cost and effectiveness. These are engineered ecosystems with an assemblage of plants, animals and microbes interacting to improve the quality of point and non-point sources of pollutants and are found to be effective in treating organic pollutants which remain even after the secondary treatment of wastewater in treatment tanks. These artificial wetlands are capable of providing various ecosystem services which are the benefits that humans obtain from nature. This involves bioremediation, water quality improvement, flood storage, nutrient cycling, habitat for fish and other organisms, and the intangible benefit of recreation and aesthetic function.

\section{Bioremediation as an ecosystem function:-}

Bioremediation is one of the most important ecosystem functions for a wetland (MA, 2005) and a restorative function in constructed wetlands. Bioremediation is the use of biological intervention for mitigating the toxic effects caused by the pollutants (Prasad and Singh, 2011) and is one of the most innovative and cost effective method used in wastewater treatment. The bioremediation activities carried out by the constructed wetlands name them as a green alternative to conventional technologies (Ranalli and Lundholm, 2008) and its use in wastewater treatment has been widely discussed. Macrophyte utilization for wastewater nutrient removal had been reported and discussed frequently (Fisher, 1988, DeBusk et al, 1989; Oron, 1990). Macrophyte being commonly used are water hyacinth, parrot feather, duck weed, reed, Azolla. Azolla, a freely floating aquatic macrophyte is a promising fern capable of carrying out bioremediation activities (Singh, 1977, 1989; Watanabe, 1982; Arora and Saxena, 2005; Arora and Singh, 2003; Sood et al, 2012; Pandey et al., 2015; Noorjahan and Jamuna, 2015; Kollah et al., 2016) and is widely used for treating municipal sewage water.

\section{Importance of Azolla in Bioremediation:-}

The genus Azolla was established by Lamarck in 1783. The name Azolla is derived from two Greek words 'azo' means to dry and 'allyo' means to kill (Jaeger, 1978). It has several advantages, the most important being the ability to grow in least time, due to which it is referred to as 'super plant' (Wagner, 1997). The presence of symbiotic nitrogen-fixing cyanobacteria, Anabaena azollae, within its leaf cavities furnishes the plant with its requirement for nitrogen. In exchange, the fern provides the endosymbiont with a protected environment and supplies it with a carbon source in the form of sucrose (Peters \& Meeks, 1989). The nitrogen sequestering potential of the organism makes it play a major role in agriculture by increased rice productivity due to application as a dual crop and a bio fertilizer (Singh et al, 1981). Azolla biomass can be used as bio-fertilizer or as a feed supplement for aquatic and terrestrial animals due to its protein; crude fiber and mineral content (Lumpkin and Plunknet, 1980). Moreover, the growth of Azolla in natural water bodies forms a mat which can help reduce the evaporation of water from them thereby making water available year round. In this century, where global warming and increased greenhouse gas (GHG) emission is taking place at a fast pace, Azolla can be successful in mitigating carbon dioxide which is a major greenhouse gas with high global warming potential. The study by Speelman et al, 2009 has given evidence on the ability of Azolla to reduce the global temperature by carbon sequestration. The study also highlighted the presence of Azolla in the Eocene period when there was a shift from the green house to ice age due to the uptake of carbon dioxide by the plant. Studies have also revealed that the plant has the ability to reduce methane (another prominent GHG) emission from paddy fields due to the thick layer formed over the surface of water (Mujiyo et al, 2016).

The present work emphasizes the efficiency of Azolla to remove nitrogen, phosphorous and carbon from secondary treated municipal effluent for use in constructed wetlands. Azolla among other commonly used ferns (duckweed, pennywort, cattail, bulrush, water hyacinth) is better suited for removal of nutrients from wastewater. This is because; the average ratio of $\mathrm{N}$ to $\mathrm{P}$ in most plant is 10:1. In most of the cases of using the common marophytic plants, phosphorous will remain even after nitrogen removal. Azolla is different as it possesses $\mathrm{N}_{2}$ fixing capacity hence it removes, phosphorous even after nitrogen has been consumed. Therefore, more efficient removal of phosphorous can be sought. In addition, they have a rapid doubling time and can be grown in aquatic media as long as favorable temperature exists.

In this backdrop, the objectives of the paper are:

1. To analyze the growth characteristics of Azolla in different medium-tap water, primary and secondary treated wastewater, 
2. To analyze the physico-chemical parameters associated with the growth of Azolla

\section{Methodology:-}

Azolla microphylla fronts were cultured in Espinase and Watanabe (E and W) medium in $20 * 25 * 5 \mathrm{~cm}$ plastic trays in polyhouse to produce healthy biomass. The biomass produced were harvested, washed with distilled water and gently blot dried to remove excess moister and used as inoculant for further experiments. Partially treated municipal effluent (primary and secondary) were obtained from Nilothi sewage treatment plant, New Delhi. Fresh Azolla fronds $(10 \mathrm{~g})$ were grown in trays for seven days. Tap water, E and $\mathrm{W}$ medium, primary and secondary treated municipal water (in triplicates) served as growth medium. Experiments were conducted with uninoculated primary and secondary treated water which served as controls, to check the natural attenuation (due to the presence of natural micro flora in water). After seven days Azolla was harvested and blot dried and final weight, doubling time and RGR were calculated. The biomass harvested were dried in over at $60^{\circ} \mathrm{C}$ till constant weights were obtained. Known amount of dry biomass from each replication was digested with triacid $\left(\mathrm{HNO}_{3}+\mathrm{HClO}_{4}+\mathrm{H}_{2} \mathrm{SO}_{4}\right.$ in ratio 9:2:1) mixture on a hot plate till a clear solution was obtained and suitably diluted with distilled water. Percentage of phosphorous in dry Azolla was calculated.

The growth characteristics of Azolla was studied by inoculating in primary and secondary treated sewage effluents. These were compared with the growth obtained in medium and tap water. Initial and final levels of nutrients like total and available phosphorous (P), Total Organic Carbon (TOC), nitrite and ammonia were analyzed following American Public Health Association standard (APHA, 1999) methods for water and wastewater. Accordingly total and available $\mathrm{P}$ was analysed by ascorbic acid method, TOC by Wakley and Black method, ammonia by nesslerization method and nitrite by colorimetric method. Physical parameters including color and $\mathrm{pH}$ were noted.

\section{Doubling time:-}

Doubling time is expressed as the number of days that are required for the biomass of the plants to double. Doubling time was calculated using the formula developed by Subudhi and Watanabe, 1981.

$$
\text { Double time }(D T)=t / r
$$

Where, t-Experiment period,

Where,

$$
r=\log \left(W_{1} / W_{0}\right) \quad 0.301
$$

$$
\begin{gathered}
\mathrm{W}_{1}=\text { Weight of Azolla } \text { after ' } \mathrm{t} \text { ' days } \\
\mathrm{W}_{0}=\text { Weight of initial inoculum } \\
0.301=\text { factor }
\end{gathered}
$$

\section{Growth Rate:-}

Growth rate of Azolla is expressed in terms of a daily relative growth rate (RGR). This is defined as the daily increment in total biomass. The relative growth rate is calculated using the formula (Subudhi and Watanabe, 1981)

$$
\begin{gathered}
R G R / g / \text { day }=\quad 0.693 \\
\text { Doubling time } \\
\text { Where, } 0.693 \text { is a factor }
\end{gathered}
$$

\section{Results and Discussion:-}

The color of primary treated wastewater was observed to change from brown to colorless after treatment with Azolla. The $\mathrm{pH}$ was found to be 8-9 which had increased slightly after growth of Azolla.

Objective 1:-Growth Characteristics of Azolla microphylla on different media

The temperature dependence of the Azolla species on the growth was analyzed by growing the Azolla samples in three different temperatures to find out the optimum temperature for the growth of Azolla sps. The comparison was made between three temperature ranges.

When the temperature was $10-20^{\circ} \mathrm{C}$, the maximum relative growth rate and minimum doubling time was shown by the medium $(0.15 \& 4.57$ respectively) followed by tap water $(0.14 \& 4.93$ resp.). The secondary treated wastewater had shown a lower doubling time compared to primary treated wastewater. This may be due to the presence of 
reduced level of ammonia in secondary treated wastewater. The percentage P was found to be highest in Azolla grown in medium followed by tap water and secondary treated water.

Maximum relative growth rate and minimum doubling time among the samples were observed in when temp was around $20-35^{\circ} \mathrm{C}$. A least doubling time of 3.66 days was shown by Azolla grown in secondary treated effluent. This was comparable to Relative Growth Rate (RGR) of medium and tap water (3.67days and 3.68 days). The highest RGR was shown by Azolla grown in primary treated wastewater. Thus the secondary treated wastewater supported better growth than standard media and tap water. The highest percentage P was found in tap water followed by secondary treated wastewater $(0.28$ and 0.27 resp.).

When the temperature ranged from $35-45^{\circ} \mathrm{C}$, the temperature was unfavorable for the growth of Azolla. The doubling time was found to be too high for all the four effluents. However, the growth rate of Azolla was found to be comparatively more in secondary treated wastewater compared to primary treated effluents. Due to the reduced growth of Azolla there was also growth of green algae in $1^{0}$ and $2^{0}$ treated effluents. This has further inhibited the growth of Azolla. The Azolla samples were also dried in oven and percentage $\mathrm{P}$ was calculated from the dry weight. The percentage $\mathrm{P}$ was higher in primary treated water followed by secondary ( 0.48 and 0.44 resp.). This higher value shown was due to presence of green algae along with Azolla.

Table 1:-Growth characteristics of Azolla in different media

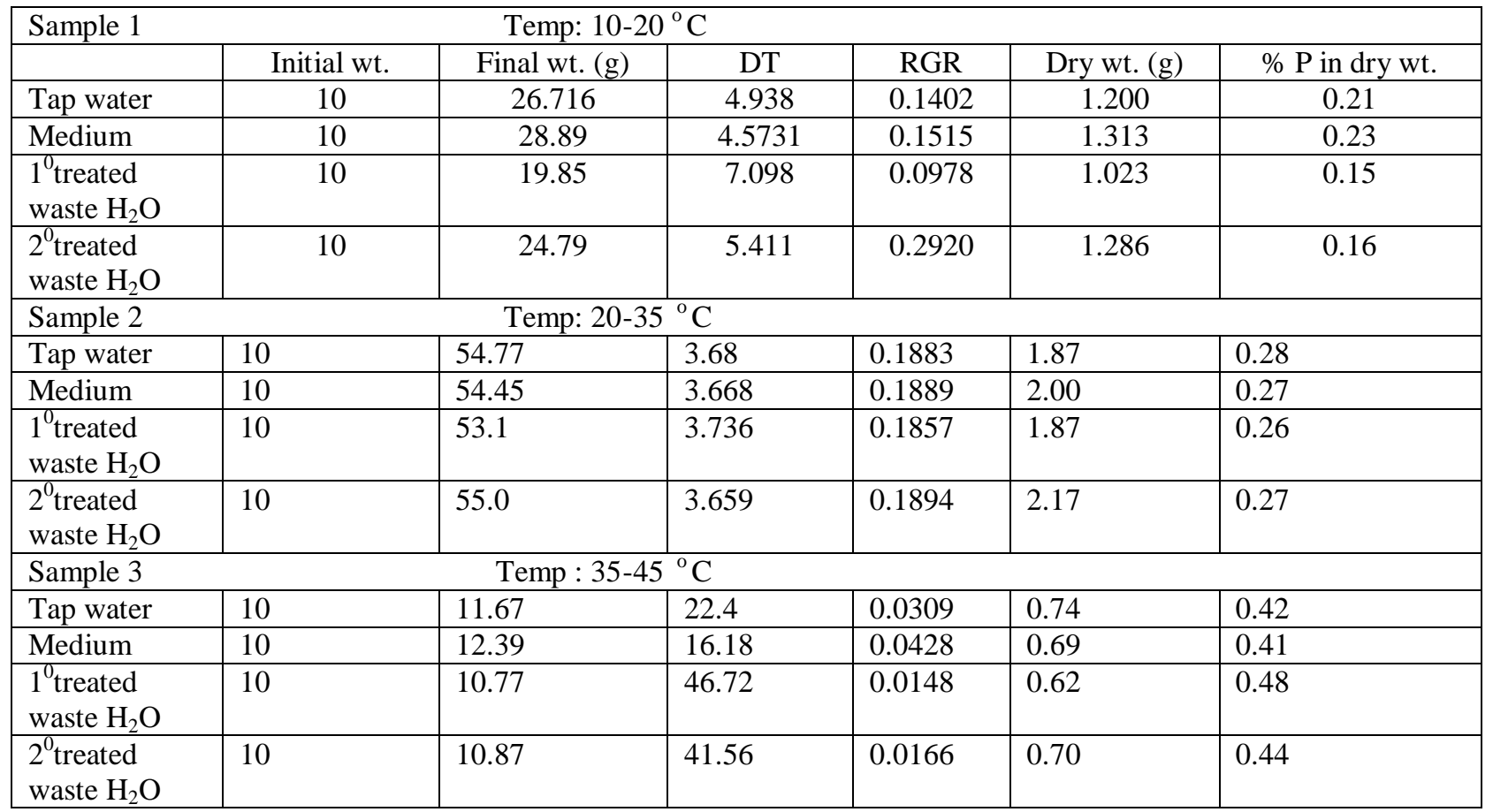

Graph 1:-Comparison of RGR of Azolla at different temperatures 


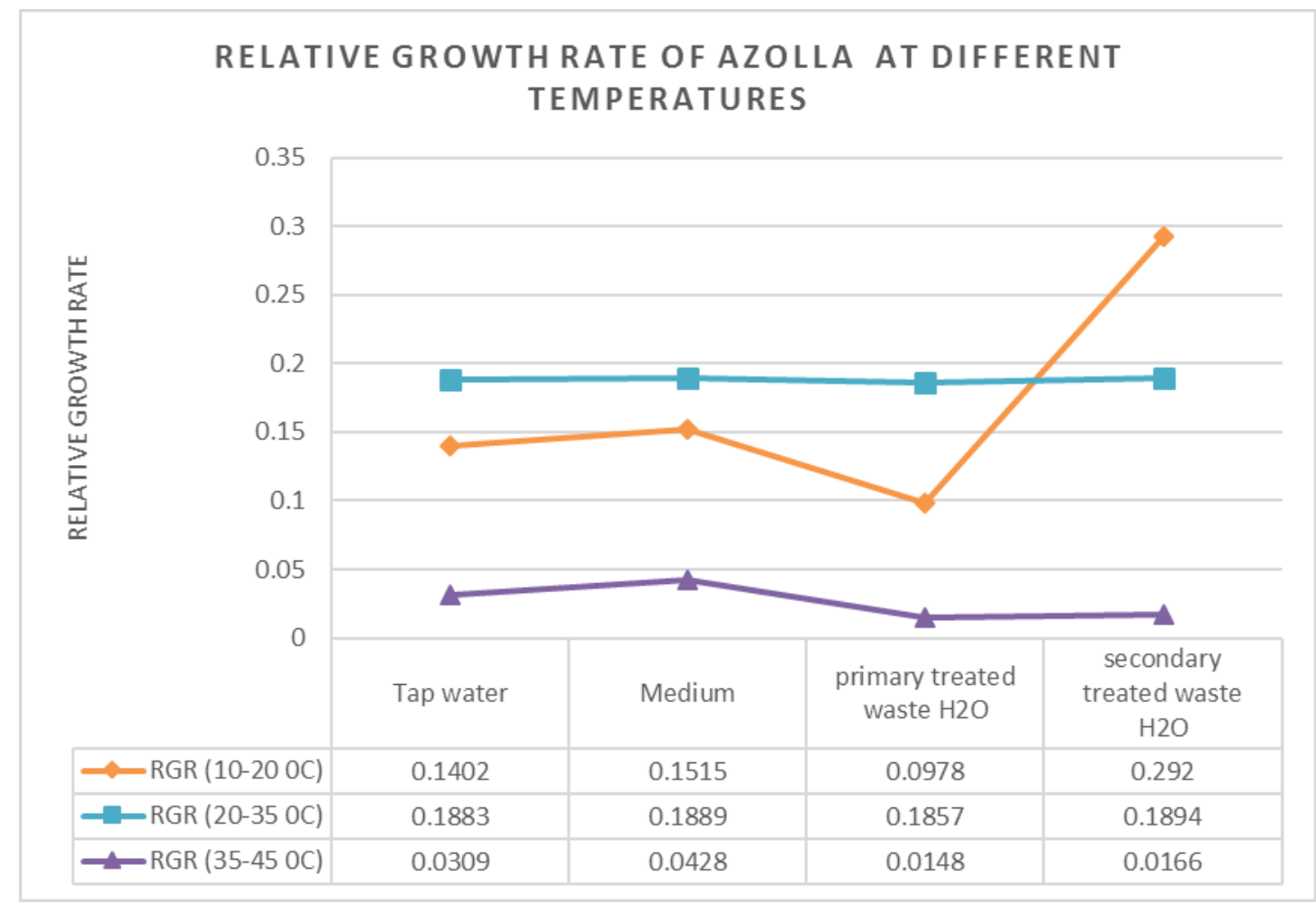

Graph 2:-Comparison of DT of Azolla at different temperatures

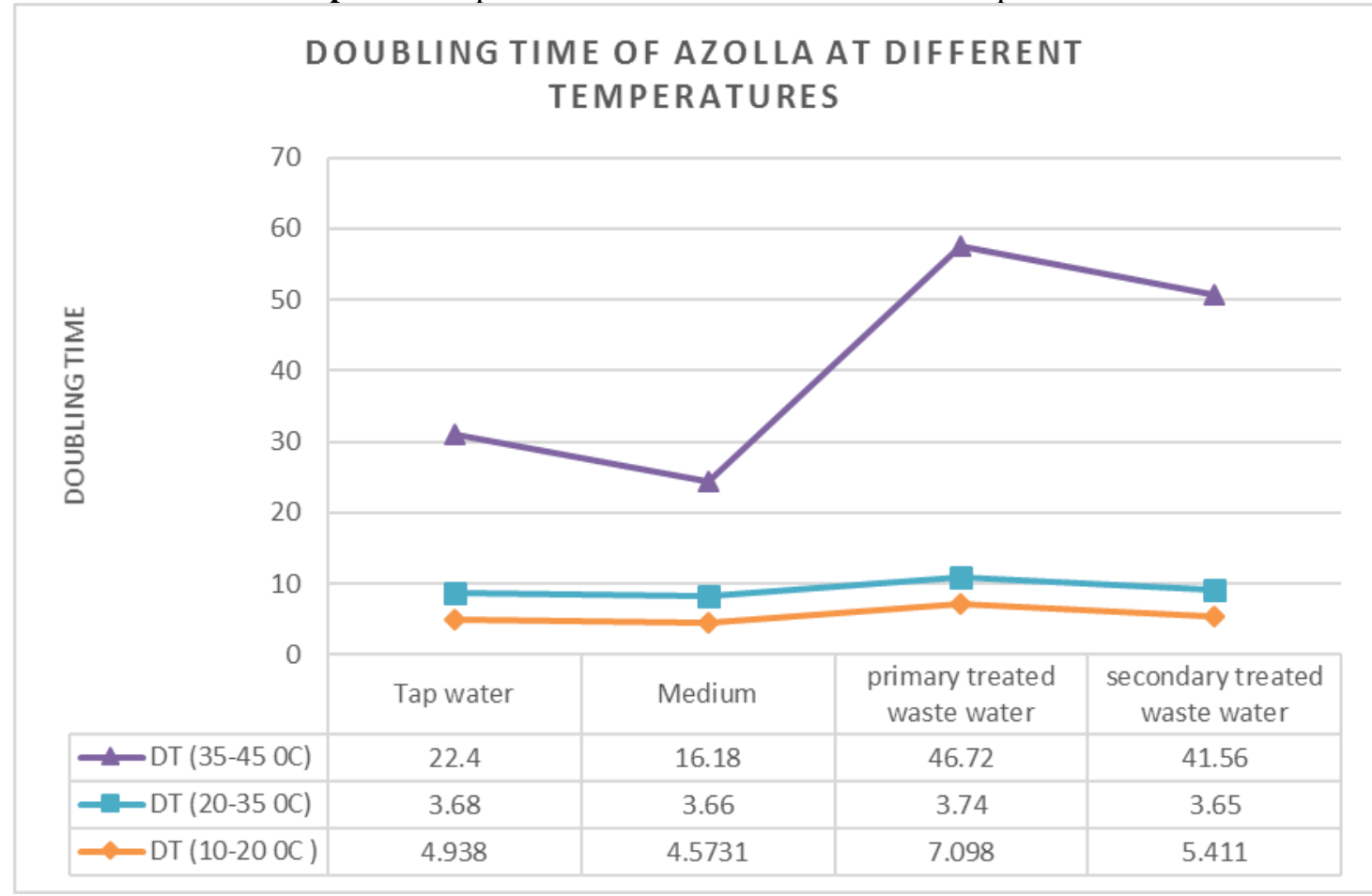

The experiment showed that the ideal temperature for growth of Azolla was found to range from 20 to $35^{\circ} \mathrm{C}$. The highest growth rate with the least DT was shown by Azolla fronts grown at a temperature range of $20-35{ }^{\circ} \mathrm{C}$. 
Objective 2:-Physico-Chemical Parameter Analysis

The water samples collected were analyzed for physical parameters like color and $\mathrm{pH}$, and chemical parameters like Total Organic Carbon, Organic Matter, Total P, Available P, Nitrite and Ammonia. The pH of the samples was in range of 7.5 to 8.9 and growth of Azolla has caused a slight increase in the $\mathrm{pH}$. The color of the primary treated wastewater was brown which had turned colorless after growth of Azolla. However, the secondary treated wastewater was colorless initially and finally.

Growth of Azolla was able to bring down the TOC, nitrite, total and available phosphorus and ammonia levels (Table 2). Growth of Azolla had brought down the total organic carbon level to 50 per cent for secondary treated water. Organic matter was 33 per cent. The Biological Oxygen Demand of both primary and secondary treated wastewater was very much within limits. Total $\mathrm{P}$ value has shown a reduction of 80 per cent in secondary treated effluent. The reduction in the phosphorous values can be attributed to the fact that phosphorous is the limiting nutrient for growth of Azolla. The ammonia levels of secondary treated wastewater had shown a reduction of 54.8 per cent. This shows that ammonium ions did not always inhibit growth and nitrogen fixation of Azolla (Kitoh et al, 1993). Nitrite content of the wastewater was also analyzed. Nitrite was found to be higher in secondary treated wastewater. This may be supported by the nitrification process of conversion of ammonia to nitrite, as ammonia content of the secondary treated wastewater was low. There was 71.4 per cent removal in nitrite content after Azolla growth. This may be attributed to the micro flora present in the wastewater and in association with Azolla microphylla.

Table 2:-Chemical parameters before and after the growth of Azolla in secondary treated sewage water

\begin{tabular}{|l|c|c|c|}
\hline $\begin{array}{l}\text { Chemical Characteristics } \\
\text { of the municipal water } \\
\text { sample }\end{array}$ & Initial level & $\begin{array}{c}\text { Final level after the growth } \\
\text { of Azolla microphylla }\end{array}$ & $\begin{array}{c}\text { Percentage Removal of } \\
\text { nutrients after the growth of } \\
\text { Azolla }\end{array}$ \\
\hline Free Ammonia $(\mathrm{ppm})$ & 2.3 & 1.04 & 54.78 \\
\hline Nitrite $(\mathrm{ppm})$ & 0.161 & 0.046 & 71.42 \\
\hline Available P $(\mathrm{ppm})$ & 7.5 & 2.35 & 68.66 \\
\hline Total P $(\mathrm{ppm})$ & 35 & 6.8 & 80.57 \\
\hline Total Organic C $(\%)$ & 0.10 & 0.05 & 50.0 \\
\hline Organic matter $(\%)$ & 0.6 & 0.4 & 33.3 \\
\hline BOD $(\mathrm{mg} / \mathrm{L})$ & 230 & 19 & 91.73 \\
\hline COD $(\mathrm{mg} / \mathrm{L})$ & 676 & 85 & 87.42 \\
\hline
\end{tabular}

Graph 2:-Change in the level of chemical parameters after the growth of Azolla microphylla

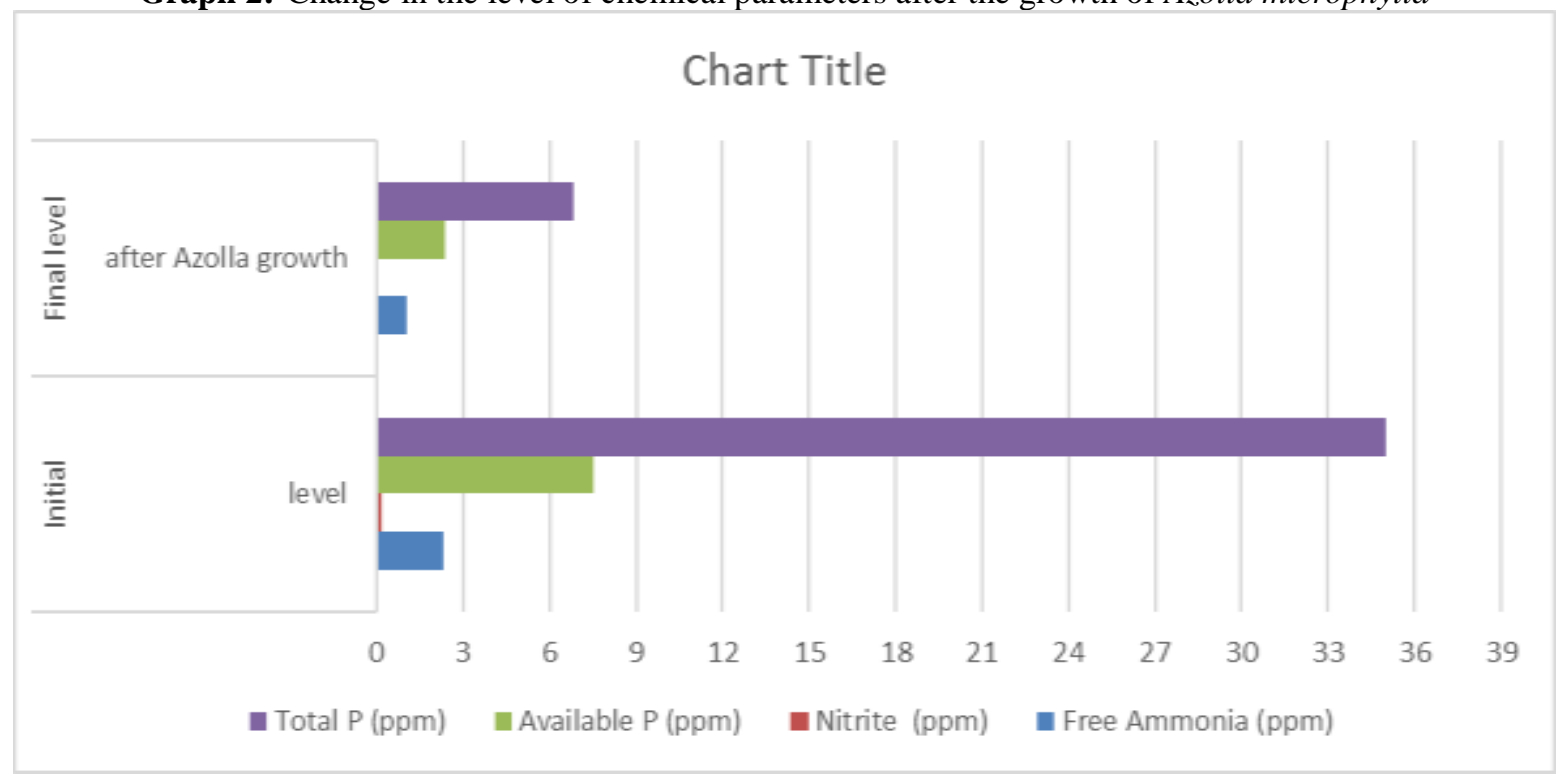




\section{Discussion:-}

The ability of Azolla to carry out bioremediation of wastewater was analyzed and the study has shown good results of removal of total organic carbon, phosphorous and nitrogen and proves to be efficient in removal of ammonia. The presence of nitrogen and phosphorus leads to the growth of algae (eutrophication) which consumes oxygen of water bodies and destroying natural flora and fauna leading to their death. Azolla growths which were found to be at peak at $20-35^{\circ} \mathrm{C}$ did not allow the growth of algae while the uninoculated controls maintained had algal growth in them. At $35-45^{\circ} \mathrm{C}$ when growth and multiplication of Azolla was negligible due to unfavorable temperature, there was growth of algae in both primary and secondary treated sewage water. Azolla uses a low cost Espinase and Watanabe medium with no nitrogen added to it (Dawar and Singh, 2002; Yadav et al., 2014). This is due to the presence of Anabaena Azollae which is in association with Azolla. It fixes atmospheric nitrogen for Azolla (Pabby et al., 2003; Arora et al., 2003). The biomass analysis shows that the greater nitrogen, phosphorus, potassium and organic content could favor the use of Azolla as a biofertilizer, especially when it grown in domestic wastewaters, and also when it is harvested from natural environments. Since Azolla can accumulate phosphorus, the concentration of this element in the plant was as higher as the growth medium was rich on phosphate. The used Azolla biomass can be applied as green manure after testing for heavy metal presence. If the presence of heavy metal is detected then it should be dried and extracted for heavy metal extraction or incinerated to prevent further recycling in the environment (Sood et al., 2012). Further the potential of Azolla can be made use of in developing operational constructed wetlands. Constructed wetlands have been set up with rooted plants like typha, phragmites, canna but the option of using Azolla in combination with these rooted plants will enhance the removal of nutrients and heavy metals with less time.

\section{Conclusion:-}

Improvement in water quality, soil and removal of pollution with the added advantage of dual cropping proves Azolla to be a promising plant for maintaining a sustainable environment. Policy makers and the scientific community are equally challenged to seek solutions to mitigate the environmental issues of ecosystem services loss including water, biomass and global climate regulation. Azolla can prove to be a promising organism for these problems. Azolla is thus an ideal plant for polishing of wastewater and can be efficiently used in constructed wetland.

\section{Acknowledgement:-}

The author would like to thank Kerala Forest Research Institute and Indian Agricultural Research Institute for providing the facility to work in the institutes and also thank Kerala State Council for Science Technology and Environment (KSCSTE) for the financial support provided for the study.

\section{Author contributions:-}

First Author-Research Fellow who carried out the work

Second Author-Research guide in the institute under whose supervision the work is done

Third Author- Senior Scientist where the laboratory work has been carried out

\section{References:-}

1. Arora, A., Pabby, A., Singh, P, K. (2003). Heavy metal accumulation by Azolla in contaminated soils. Proc. $18^{\text {th }}$ Ann. Intl. Conf. on Contaminated Soil Sediments and Water), Vol 8 Amherst Scientific Publishers, Amherst Scientific Publishers Amherst, USA. 8, 39-48

2. Arora, A., Saxena S. (2005). Cultivation of Azolla microphylla biomass on secondary-treated Delhi municipal effluents. Biomass and Bioenergy. 29, 60-64

3. Arora, A., Saxena, S., Shah, R. (2009). Aquatic microphyte Azolla for Nutrient Removal from Wastewaters in Constructed Wetlands. Proceedings of International Conference on Energy and Environment. Environmental Energy. 185-188

4. Arora, A., Singh, P, K. (2003). Comparison of biomass productivity and nitrogen fixing potential of Azolla spp. Biomass and Bioenergy. 24, 175-178.

5. Bassi, N., Kumar, M, D., Sharmac, A, P. Saradhi,P. (2014). Status of wetlands in India: A review of extent, ecosystem benefits, threats and management strategies. Journal of Hydrology. 2, 1-19

6. Central Pollution Control Board. (2008). Status of water quality in India 2007, New Delhi, India: CPCB.

7. Dawar,S., Singh, P, K. (2002). Comparison of Soil- And Nutrient-Based Medium for Maintenance of Azolla Cultures. Journal of Plant Nutrition. 25(12), 2719-2729 
8. DeBusk, T. A., Reddy, K, R. Hayes T, D., Schwegler, B, R. (1989). Performance of a pilot-scale water hyacinthbased secondary treatment system. Journal WPCF, 61, 1217-1224.

9. Elmachliy, S., Chefetz, B., Vidal, L., Canals, A., Gedanken, A. (2010). Removal of silver and lead ions from water wastes using Azolla filiculoides, an aquatic plant, which adsorbs and reduces the ions into the corresponding metallic nanoparticles under microwave radiation in $5 \mathrm{~min}$. Water Air Soil Pollution. 365-370

10. Fisher, J. P. (1988). Wastewater treatment using aquatic plants. In (eds), Alternative Waste Treatment Systems, Rao Bhamidimarri, Elsevier Applied Science, Palmerston North, New Zealand: 34- 44.

11. Jaeger, E, C. (1978). A Source-Book of Biological Names and Terms, $3^{\text {rd }}$ ed. Charles C Thomas, Publisher, Sringfield, III. 32

12. Kitoh, S., Shiomi, N., Uheda, E. (1993). The growth and nitrogen fixation of Azolla filiculoides Lam. in polluted water. Aquatic botany. $46,129-139$

13. Kollah, B., Patra1, a, k., Mohanty, S, R. (2016). Aquatic microphylla Azolla: a perspective paradigm for sustainable agriculture, environment and global climate change. Environ Sci Pollut Res. 23:4358-4369

14. Lumpkin, T, A., Plucknett, D, L. (1980). Azolla: Botany, physiology, and use as a green manure. 34 (2), $111-153$

15. Millennium Ecosystem Assessment (MA), (2005). Ecosystems and Human Well-being: Biodiversity Synthesis. World Resources Institute, Washington, DC.

16. Mujiyo, Sunarminto, B, H., Hanudin, E., Widada, J., Syamsiyah, J. (2016). Methane Emission on Organic Rice Experiment Using Azolla. International Journal of Applied Environmental Sciences. 11 (1), 295-308.

17. Noorjahan C, M., Jamuna, S. (2015). Biodegradation of Sewage Waste Water Using Azolla Microphylla and Its Reuse for Aquaculture of Fish Tilapia Mossambica. Journal of Environmental Science, Toxicology and Food Technology. Vol. 9(3). 75-80

18. Oron, G. (1990). Economic considerations in wastewater treatment with duckweed for effluent and nitrogen renovation. Journal WPCF, 62, 692-696.

19. Pabby, A., Prasanna, R., Singh, P, K. (2003). Azolla anabaena symbiosis from traditional agriculture to biotechnology. Indian Journal of Biotechnology. Vol.2, 26-37

20. Pandey, A., Verma, R, K., Mohan, J., Mohan, N. (2015). Utilization of Azolla aquatic plant as phytoremediation for treatment of effluent. International Journal of Applied Research. 1(2): 28-30

21. Peters, G. A., Meeks, J. C. (1989). The Azolla-Anabaena symbiosis: basic biology. Annual Review of Plant Physiology and Plant Molecular Biology 40, 193-2 10

22. Prasad, S, M., Singh, A. (2011). Metabolic responses of Azolla pinnata to cadmium stress: photosynthesis, antioxidative system and phytoremediation. Journal of Chemistry and Ecology. 27(6), 543-555

23. Ranalli, M., Lundholm, J, T. (2008). Biodiversity and Ecosystem function in constructed ecosystems. CAB Reviews Perspectives in Agriculture Veterinary Science Nutrition and Natural Resources. 3, 1-16.

24. Sachdeva, S., Sharma, A. (2012). Azolla: Role in Phytoremediation of Heavy Metals. Paper from Proceeding of the National Conference "Science in Media 2012" Organized by YMCA University of Science and Technology, Faridabad, Haryana (India)

25. Singh, P, K. (1977). Azolla fern plant-rice fertilizer and chicken feed. Kerala Karshakan. 26, 5-6.

26. Singh, P, K. (1989). Use of Azolla in Asian Agriculture Applied Agricultural Research. 4(3), 149-161.

27. Singh, P, K., Panigrahi, B, C.,Satpathy, K, B. (1981). Comparative efficiency of Azolla, blue green algae and other organic manures in relation to $\mathrm{N}$ and $\mathrm{P}$ availability in a flooded rice soil Pl Soil. 62, 35-44.

28. Sood, A., Uniyal, P, L., Prasanna, R., Ahluwalia, A, S. (2011). Phytoremediation potential of Aquatic Macrophyte, Azolla. Ambio, DOI 10.1007/s13280-011-0159-Z

29. Speelman, E, N., Van Kempen, M, M., Barke, J., Brinkhuis, H., Reichart, G,J., Smolders A,J, Roelofs J,G., Sangiorgi, F., de Leeuw, J,W., Lotter, A,F., Sinninghe Damsté, J,S. (2009). The Eocene Arctic Azolla bloom: environmental conditions, productivity and carbon drawdown. Geobiology. 7(2), 155-170.

30. Standard Methods for the Examination of Water and Wastewater. (1999). American Public Health Association (APHA), American Water Works Association, Water Environment Federation

31. Subudhi, B, P, R., Watanabe, I. (1981). Differential Phosphorus requirements of Azolla species and strains in phosphorus limited continuous culture. Soil Sci.Plant Nut. 27(2), 237-247

32. Vymazal, J. (2010). Constructed Wetlands for Wastewater Treatment. Water .2, 530-549

33. Wagner, G, M. Azolla: A review of its biology and utilization. (1997). Botanical Review. 63, 1-26.

34. Watanabe, I. (1982). Azolla-Anabaena symbiosis-it's Physiology and use in tropical agriculture. In: Microbiology of tropical Soils and Plant Productivity. 169-185.

35. Watanabe, I., Liu, C, C. (1992). Improving nitrogen-fixing systems and integrating them into sustainable rice farming. P1. \& Soil. 141, 57-67.

36. Yadav, R, K., Abraham, G., Singh, Y V., Singh P K. (2014). Advancements in the Utilization of Azolla-Anabaena System in Relation to Sustainable Agricultural Practices. Proceedings of Indian National Science Academy 80. 2 , 301-316 